\title{
Eduardo Ibarra-Colado*
}

\section{Future University in Present Times: Autonomy, Governance and The Entrepreneurial University}

The paper discusses the main challenges confronted by Mexican government agencies and universities to deal with the model implemented since the late 1980s in the context of neoliberalism and globalization. Such challenges are associated with the tendencies observed at three levels. First, the transformation of the sense and content of the autonomy regime of the university and its legal principles. Secondly, the emergence of governance as a strategic condition to perform institutional ends and projects in a market driven context. Finally, the gradual conformation of the entrepreneurial university under new organizational arrangements through which it is trying to perform their functions effectively and legitimately to fulfill current market and economic demands. The paper concludes by discussing some alternative arrangements, thus advocating the transformation of the university system in order to confront the challenges resulting from new emerging contexts, but without abandoning its commitment to social development and equity and its historical role as a main cultural institution for society.

Key words: Globalization, Autonomy, Governance, Participation

* Eduardo Ibarra-Colado is Head of the Department of Institutional Studies at the Autonomous Metropolitan University, Campus Cuajimalpa and professor of Management and Organization Studies. Address: Department of Institutional Studies, Universidad Autónoma Metropolitana-Cuajimalpa, Pedro Antonio de los Santos \#84, Col. San Miguel Chapultepec, Miguel Hidalgo 11850, Mexico, D.F., Tel: Intl. + (52 55) 5516 6733, ext. 119, e-mail: eibarra@correo.cua.uam.mx and ibarra57@hotmail.com, web page: http://estudios-institucionales-uamc.org/

** Article received: December 12, 2006

Revised version accepted after double blind review: April 22, 2007. 


\section{Introduction}

Concepts like "accountability" and "efficiency" represents the current condition of modernity as a mode of existence based on management of one and all aspects of social life. These concepts indicate that the universalization of modernity is already done, shaping a system in which the "conduct of conducts" of institutions and individuals are operated by the application of abstract rules to certificate the "normal" behavior. The current condition of modernity, then, is based on surveillance and distrust (Power 1997).

In Foucault terms, society is living in the stage of governmentality (Foucault 2003a, 2003b), in which the goals of human action are defined and controlled by the State in accordance with economic power, but the definition of the means is increasingly in hands of institutions and individuals. The system operates by bureaucratic unpersonalized technologies to steering from a distance, so it can guarantee that each conduct, although the existence of some degree of freedom, will fit with the standard. This new mode of existence was built during the last three decades or so, and it is associated with the emergence and generalization of neoliberalism and globalization (Ibarra-Colado 2006a).

This is the scenario of the recent transformations of the university in countries like Mexico; it is a radical process of change that has implied the redefinition of its institutional meaning and role to fulfill the needs of markets and the economy. The deepness of this change and the social conflicts it entails can be appreciated when consider the role played by the university in Mexico, an institution that emerged as a social institution representing the Mexican Revolution ideals of justice, equity and social progress. In this ideological context, education has been considered a social right, and knowledge a public good that should not be privately appropriated. The university is a social institution that has been functioning for a long time as the basic cultural reference point of society.

To characterize this process, it is necessary to go back to the $1960 \mathrm{~s}$, since then there was a clear awareness of the expansion and gradual diversification of higher education. It is also important to remember the efforts in institutional reorganization implemented based on legislative reforms from the late 1970s. In fact, those reforms were an indispensable condition for implementing the modernization of the university system a decade later. Without those elements, it would be difficult to understand the radical nature of the changes carried out during the 1990s. They encompassed almost every aspect of higher education, incorporating new practices and modes of coordination and conduction of the university system which, in turn, have encouraged the creation of competitive mechanisms for regulating university budgets, the payment of academic staff and the assignment of resources for science and other institutional programs (Ibarra-Colado 2001; see also 2003: 325-437).

However, this major transformation should not be considered only in the specific spaces of education and science; they entail the transformation of the current modes of existence of society all around the world, because they define the rules of operation of general economic and social relations. What is being addressed here is a change from one era to another, marked by institutional modifications that deeply redefine 
the rules of the game and calculation, reorienting social practices and collective action (Ibarra-Colado 2003: 307 note 14). These transformations remain hidden behind a set of measures that has been instrumented by government agencies over the last 15 years, and it is precisely what the analysis must disclose to understand the challenges confronted by universities nowadays.

The modernization of Mexico's university system is a process that is not yet complete and still requires additional transformations. It has followed a project clearly based on the recommendations of the OECD (1997). The Association of Mexican Universities projected in 2000 its own vision of the university system considering a period that extends to the year 2020 (ANUIES 2000). This document was the base of the National Education Program 2001-2006 (SEP 2001), designed to consolidate the modernization process that began a decade before. Among other elements, this reforming program implied:

- the expansion of the higher education system;

- the consolidation of its diversification and the differentiation of the profile and projects among institutions;

- the incorporation of research universities into the international markets for production and transmission of knowledge;

- the operation of compensatory mechanisms to facilitate a more balanced development of the overall system, as well as of subsystems others than the university one and their institutions;

- the consolidation of modes of regulation based on the implementation of standardized procedures (e.g. evaluation and accreditation programs) to create opportunities for performance-based exchange;

- the establishment of a diversified financing system based on planning, evaluation and accountability;

- the transformation of the organizational forms and management systems to enhance their self-management capacities to confront new open, complex and uncertain contexts based on competition, exchange and cooperation;

- the establishment of a new regulatory system of academic work that strengthens the professionalization of academic staff, including aspects such as remuneration based on merit-pay systems, postgraduate education and mobility;

- the comprehensive revision and modification of the legal regulations of higher education to guarantee long-term stability and certainty;

- the consolidation of quality in teaching through the permanent revision, updating, and flexibilization of undergraduate and graduate academic programs, encouraging student mobility, and assisting low-income students to continue their educational career.

Although the actions proposed here might be clear in terms of their requirements and scope, their implementation presented serious difficulties because of a context marked by problems, both internally and externally. The transformation of universities in Mexico is occurring in a complex context characterized by tension between global integration and local realities; poverty, lack of resources, cumulated limitations and deep contrasts and differences between regions and states makes it extremely risky to pro- 
ject what the Mexican university system will look like by the year 2020. This is a debate that will continue for some time; however, the current effects of the governmental actions may be clarified based on recognizing what has already changed, conditioning to some degree the future of universities.

Considering this approach, the paper discusses the main challenges confronted by Mexican government agencies and universities to deal with the model implemented since the late 1980s in the context of neoliberalism and globalization. Such challenges are associated with the tendencies observed at three different but interrelated levels. First, the transformation of the sense and content of the autonomy regime of the university and its legal principles, by increasingly constituting itself and narrowing as "practical" or "supervised" autonomy. Secondly, the emergence of governance as a strategic condition to perform institutional ends and projects in a market driven context, because of the redefinition of the role of the State as the unconditional guarantor of resources for institutions. Finally, the gradual conformation of the entrepreneurial university under new organizational arrangements through which it is trying to perform their functions effectively and legitimately to fulfill current market and economic demands. The paper concludes by discussing some alternative arrangements, thus advocating the transformation of the university system in order to confront the challenges resulting from new emerging contexts, but without abandoning its commitment to social development and equity and its historical role as a main cultural institution for society.

\section{Globalization: from the world-class to imprisonment and exclusion}

The transformation of higher education must be placed in the broader context of globalization, because it has implied the geopolitical reorganization of the world based on the regional integration of markets and the redefinition of the terms of the international division of labor. This is a matter of understanding the world in new terms, substituting the traditional analytical reference point, the Nation-state, with disperse, less-defined and constantly-changing global or regional networks in which corporations, governments and universities collaborate developing joint projects based on new arrangements of capital, people and ideas (Kanter 1997: 42-43; Leydesdorff/Etzkowitz 2001).

To understand the new position of the university in the world, and specifically the position of Mexican universities in relation to the world and its own local realities, it is necessary to clarify this new global architecture (Rodríguez/Alcántara 2001). To speculate a bit using an architectural metaphor, globalization can be understood as a building with three floors. The upper floor is where major world business takes place. This is the floor where large transnational corporations can be found, together with high technology and innovation, as well as post-bureaucratic organizational forms, hyper-flexibility, and virtual arrangements to work at a distance, with real-time relations based on e-commerce and other online devices, and with knowledge labor based on team-work to develop innovative projects. In short, this is the world's new economy based on academic capitalism (Slaughter/Rhodes 2004) and the new forms of production of knowledge (Gibbons et al. 1994).

From these world-class regions, it is possible to take note of the meaning of the new policies and practices supported by the World Trade Organization and other International Financial Institutions (Wallach/Woodall 2004) to cover transversally the 
markets of the planet. They define new modes of functioning for the economy, the State and services, and within the latter, education, applied scientific knowledge and technological innovation. While varying in terms of local conformation and specific operation, the policies and programs for restructuring higher education in different countries around the world converge under the paradigmatic imperatives of privatization, deregulation and competitiveness. They facilitate the conformation of new global markets on trade in services under supra-national regulation rules: the current negotiation of the General Agreement on Trade in Services (GATS) is the main piece of this trend (Sauvé 2002; compare with Barrow 2002 and Verger/Bonal 2006). The relevance of these policies lies in the consolidation of a dual structure segmentation of the higher education system, in which research centers and graduate programs get better supports in comparison with the undergraduate schools and programs. This internal differentiation tends to favor a better articulation of the institutions and programs of the research sector with the needs of the economy, supporting innovation and competitiveness of local enterprises in global markets (Ibarra-Colado 2002).

The ground-level floor of the building is represented by a kind of "saturnian model" in which satellite subcontracted enterprises-the new dark satanic mills, the sweat mills and the maquilas in underdeveloped countries all around the world, revolve around a huge transnational corporation. Mass production, large inventories and increasingly precarious labor in these proslavery Taylorist-Fordist factories constitute the way the world-class corporations transfer some of their costs to their subcontractors. This is the only way to maintain and celebrate their just-in-time flexibility, their zero inventories and their "excellence" high skilled and well-paid workers.

This is the floor where the other higher education segment can be found, the impoverished level of the undergraduate education. These schools and programs attend the majority of the population in higher education, but they have been increasingly impoverishing because of systematic government budgetary cuts. They confront the paradoxical task of teaching large contingents of citizens in a standardized way for routine work, but in a world without employment for everyone, giving shape to the "knowledge factories" that today represent the dark side of academic capitalism (Aronowitz 2000; Hayes/Wynyard 2002).

Lastly, the new global world building has a bottom floor that is concealed, humid and dark, functioning like a basement for depositing everything that is not used, what is worthless or that gets in the way. This is the floor for those who are excluded. It is an imprisoned place to contain the masses without consumption capacity in a society based on the cult of consumerism and the exaltation of the desire to possess. On this floor, everything is in penumbra and there is no future, but only heavy cudgels and padlocks to confront the resistance of these new wretched, mendicants and vagrants, all of them condemned because of their only fault, to be unemployed (Castel 2002: 379). These masses must be restrained because they endanger the structural stability of the global building of the world-class corporations.

According to this metaphorical interpretation about globalization, it no longer needs to be asked about whether societies belong to a certain Nation-state, and where these Nation-states are positioned in the old world geography of bipolarities and cold war. Rather, the question is a matter of how each of the organizations, groups and in- 
dividuals around the world is positioned in this global building, the place it occupies, the floor where it resides, the lights that enlighten it, or the shadows that hide it.

\section{Mexico's higher education system: a brief profile}

With this representation of globalization in mind, the meaning of recent transformations in Mexico's higher education system becomes clear. This process have produced a new organizational arrangement in which few institutions and groups participate in the exclusive world of the upper floor, in contrast with a greater sector of the system that is loosing governmental support. The last piece of the picture corresponds to a majority of the population who do not have any chance to enter higher education to find any opportunity to improve their level of life.

Mexico's higher education system has developed in an ambivalent manner. Since the approval of the last Organic Law of UNAM in 1945, it can be noted highly significant achievements (Rodríguez/Casanova 2005: 53-55); however, it is also necessary to acknowledge the serious lags that persist. In a period of only 60 years, a very complex, diversified system was built, with an increase from 39 institutions in 1950 to 1,774 in 2005 (ANUIES 2006: 19). Also, in 1950 public university education, made up of 16 institutions, was nearly the only option to study and only within reach for young people in the upper classes. In contrast, today's higher education system offers to broader sectors of society a range of highly diversified options that include public universities (45), technological institutes (147), technological universities (60), teacher training institutions (467), private institutions (976), and other institutions under the jurisdiction of the Department of Education or other government departments (67). Besides, the number of students enrolled in higher education multiplied 8.4 times between 1970 and 2006, signifying a current total of just over 2.3 million students nowadays (Fox 2006: 47, 48).

Nevertheless, despite the effort required to build a system with these dimensions and complexities in only half a century, it continues to be small, and to suffer structural budgetary neglect associated with recurrent economic crises for more than two decades now. It also has only a few academic research groups that are truly consolidated, and there is still a high degree of centralism, producing a considerable concentration of efforts and resources. Mexico is a country of 103.3 million inhabitants. However, the higher education academic staff has only 246,523 professors, of whom only 57,290 are full time (SEP 2003: 46, 48). Of those, the Mexican government only recognizes the existence of 39,084 researchers and of that number, only slightly over 12,500 are acknowledged as high-level researchers in the National System of Researchers (Fox 2006: 73). Only over $22 \%$ of the $18-22$ year-old population can access this educational level. Of those students, only 6.6\% continue with graduate studies (Fox 2006: 47). Additionally, during the last decade (1995-2004), only 9,725 PhD students graduated, just under an annual average of less than 1000 (CONACYT 2005: 36).

In addition, Mexico has only a few institutions dedicated to scientifictechnological research. Efforts in this area are concentrated in UNAM, UAM, CINVESTAV, IPN, the 28 SEP-CONACYT centers (CONACYT 2005: 76), and some other research centers in the public sector. The situation is clearly expressed when 
considered that Mexico allocated only a $0.37 \%$ of the GDP for federal spending on science and technology in 2006 (Fox 2006: 69; CONACYT 2005: 16, 18).

Finally, according to official statistics, the private sector participates with $30 \%$ of national investment in research and experimental development $(\mathrm{R} \& \mathrm{D})$, but this investment is carried out by only the 300 largest private corporations in Mexico, corresponding to $0.01 \%$ of the total (Fox 2006: 70). Instead of investing in R\&D, most enterprises prefer to transfer "junk" technology no longer used by world-class corporations.

The current state of higher education and science was recently synthesized in the following terms:

Public spending per student in higher education decreased in constant 2000 prices from 22,756 pesos in 1982 to 17,482 in 2002. Furthermore, within OECD countries, Mexico has the lowest spending in higher education per student. Its annual spending is equivalent to less than half of the average for countries in that organization, and a fifth of spending in the United States. The number of students enrolled in [public] universities remained stagnant during the last decade, while it tripled in private universities. The seriousness of this panorama is best expressed by the gross rate of schooling, which was between 15 and $19 \%$ in 2000 , in contrast to $23 \%$ in the Dominican Republic, $29 \%$ in Barbados, $30 \%$ in Costa Rica, 31\% in Panama and Chile, and 36\% in Argentina. This gap is even wider in comparison to countries such as South Korea with a rate of $68 \%$, the United States with $81 \%$, and Canada with $87 \%$. Furthermore, as evidence of the country's limited capacity to impel development, Mexico has 214 scientists and engineers working in R\&D per million inhabitants, in comparison to 532 in Costa Rica, 660 in Argentina, 2,193 in South Korea, 2,719 in Canada, 2,831 in Germany, and 3,676 in the United States. The culminating point in this situation refers to the growing debt accumulating in the majority of the country's public universities, endangering their viability. (Cazés et al. 2003: 127-128)

These figures clearly illustrate a panorama that is not very encouraging, reaffirming the marginal position of Mexican universities in the new markets of production of knowledge. According to the new international division of knowledge labor in the global world, it is clear that the production of front line knowledge and the education of Presidents, State Secretaries and leaders of corporations for less developed countries are in charge of the Ivy League and other highly ranked universities of Europe (THES 2006). In the case of Mexico, some elite private institutions and a few public research centers with accredited graduate programs complement this function. In contrast, the adaptation and consumption of technologies transferred from the developed countries, and the education of the middle and low-level white-collar professionals and technicians required for operating bureaucratic structures and routine systems of enterprises and the public sector, are reserved for undergraduate higher education schools and technological universities and institutes (Delgado/Saxe 2005).

\section{The problem: market versus society}

At this point, a crucial question emerges. Have the transformations experienced in higher education made it possible to suppose that Mexico will be able to insert itself within a reasonable period in the international circuits of knowledge production, or are these transformations oriented toward reinforcing its subordinate role focused on technology transfer and training of low and medium-level technicians and professionals? 
What is clear is that in Mexico, the most significant progress from the last decade has been the transformation of the institutional structure of higher education and science, and the corresponding regulatory systems and procedures based on performance and competition. This new conformation is a necessary condition for overcoming the accumulated lag and, by the end of the first decade of this century, narrowing the gap separating Mexico's education and scientific indicators from those of countries with a similar development. However, without increasing resources and placing a State policy that positions education and science as the nation's highest priority, any efforts undertaken will most surely turn into new failures. In other words, it is necessary to define clearly the position that Mexico's education and science needs to play to support economic and social development and to be able to participate in the international arena of knowledge, and the actions that will translate this intention into new realities.

Undoubtedly, there are advances in this respect in a number of areas, and it is now possible to note some institutions and programs operating under Mode 2 of production of knowledge: they are closely linked to application and innovation, transdisciplinarity, new organizational forms, social responsibility and quality control (Gibbons et al. 1994; Nowotny et al. 2001). In spite of the differences between countries, these arrangements will be strongly enhanced during the coming years promoted by the Free Trade Agreements and the Internationalization of Higher Education (Barrow et al. 2003; De Wit et al. 2005). The gradual forming of networks of knowledge and innovation based on exchange and cooperation (Casas 2001; Luna 2003), and of niches that are beginning to fight for a space in the upper floor of the global building should not, however, be oriented exclusively at market forces, trade and accumulation. Once again, what is essential in countries like Mexico is to recognize the strategic relevance of education and science to support simultaneously economic development and the elimination of huge inequalities and poorness. ${ }^{1}$

Mexico's "academic capitalism," 2 although still only emerging, has been promoted for slightly over a decade now, through policies and programs designed to encourage the articulation of research projects and graduate programs with the economy, in a context of deregulation and competitiveness. A series of measures oriented in this direction have been implemented:

a) The consolidation of the already mentioned dual structure of the higher education system with an increasing menu of educational options and modalities and an increasing participation of private sector;

$1 \quad$ President Fox administration acknowledged the existence of 53.7 million poor in Mexico (Cortés et al. 2002: 15; also World Bank 2004), a figure considered by some researchers to be conservative (see Boltvinik/Hernández 2002), while it does indicate the seriousness of the problem confronted in terms of social equity and justice.

2 This term was proposed by Slaughter and Leslie (1997) and re-elaborated by Slaughter and Rhoades (2004) to indicate the use by universities of the human capital represented by their academics for increasing their income. In this way, the term "academic capitalism" suggests the set of economically motivated initiatives and behaviors of universities and their members to assure the attainment of outside resources needed to sustain themselves and to continue to operate. 
b) The operation of mechanisms for extraordinary, competition-based, financial assistance designed to support research centers in better adapting to the scientific-technological requirements for the country's economic development and the modernization of its industries; ${ }^{3}$

c) The operation of programs to guarantee the expansion of full time academic staff in Mexico's public universities, assuring their professionalization through formal academic qualification; 4

d) The assistance to low-income students to promote equity in education, on the one hand, and to support the expansion of graduate education, on the other; 5

e) Finally, the approval of a new legal ordering some new promotion programs to facilitate the linkage between science and technology activities and the needs of the economy. ${ }^{6}$

Considering this context of differentiation and segmentation besides the new conditions that favor joint projects and collaboration, it is important to note the recent

3 Among these funds is the Comprehensive Program for Institutional Strengthening (Programa Integral de Fortalecimiento Institucional-PIFI), the Fund for Extraordinary Assistance to State Public Universities (Fondo de Apoyo Extraordinario a las Universidades Públicas Estatales-FAEUP) and the Program for the Normalization of the Administrative Infrastructure (Programa para la Normalización de la Infraestructura Administrativa-PRONAD). See for this and the next notes the webpage of CONACYT:

http://www.conacyt.mx/Servicios.html.

4 In this case, it can be mentioned the Program for Improvement of Teaching Staff in higher education institutions (Programa de Mejoramiento del Profesorado de las instituciones de educacion superior-PROMEP), the National System of Researchers (Sistema Nacional de Investigadores-SNI), Support of Basic Science Research Projects (Proyectos de Investigación Cientifica Básica-PICB), Sector-based and Mixed Funds for Assistance to Science and Technology (Fondos Sectoriales y Mixtos de Apoyo a la Ciencia y Tecnología), the Fund for Retaining and Repatriating Mexican Researchers (Fondo para Retener en México y Repatriar a los Investigadores Mexicanos) and, finally, International Cooperation Programs.

5 To this end the following opportunities were recently created: the National Program for Scholarships for Higher Education (Programa Nacional de Becas para la Educación SuperiorPRONABES) and the Program for Mobility in Higher Education in North America (Programa para la Movilidad en la Educación Superior en América del Norte) which grants assistance for studying at the higher education level at participating institutions in Mexico, the United States and Canada. And at the graduate level, there is the CONACYT Program of Scholarships for Graduate Studies (Programa de Becas para Estudios de Posgrado) and the Comprehensive Program for Strengthening Graduate Programs (Programa para el Fortalecimiento del Posgrado Nacional-PFPN).

6 The intention is to consolidate a regulatory system for scientific-technological production designed for incorporating technological development into production processes, as a necessary requirement for the increased productivity and competitiveness needed by national industry. In 2002 the Congress approved a new Law on Science and Technology and the new Organic Law for the National Council of Science and Technology (Diario Oficial 2002). In addition, the government has been operating some promotion programs like AVANCE or some fiscal incentives to support the involvement of enterprises in R\&D activities. 
transformation of the meaning of autonomy. It is a normative regime established in the Mexican Constitution for most of the public universities and some higher education institutions, and the ways in which it has been translated into specific institutional management and governance arrangements. The most evident changes are related with the utilization of new criteria like efficiency, productivity and competition to support university decision making and actions.

This project is driving the university system to respond effectively to market demands and the economy, displacing to a second place its historical commitment with social justice and equity. This has led to the development of a new social dispute over the university, confronting the essential meaning of education and knowledge as a social right with the new emerging one that considers education simply as a service that must be bought in the market. This dispute can be exemplified in the dispute between gratuitousness and commodification, but their implications in terms of the transformation of practices, organizational forms and identities are enormous and generally misplaced (Ibarra-Colado 2001, 2003).

Nevertheless, beyond these two extreme points, it can be appreciated a varying combination in which a university system linked to society has not been totally discarded, nor the total imposition of a new university system linked to the market. The search for a new model that balances and manages the tensions between market and society has become necessary in order to develop a new institution that can be inserted into the emerging tendencies of knowledge production without sacrificing its commitment to society's well-being. Unfortunately, the most visible trends seem to be inclined toward prioritizing market considerations.

\section{A new practical autonomy against self-determination}

As mentioned earlier, Mexico witnessed one of the most significant transformations in the history of universities during the last decade of the $20^{\text {th }}$ century. The changes implemented in a mere ten-year period modified radically the practices and forms of organization and governance in the various institutions as never before. Through government strategies, policies and programs for administering the university system and each one of their institutions (Ibarra-Colado 2003: 268), it becomes evident the great capacity of the new liberal technologies of regulation implemented to gain a better control over the functioning of the universities and the work of their academic staff. These new technologies have the capacity to modify without important resistances the nature, content and organization of academic work and institutional practices. The effectiveness of these technologies lies on their capacity for operating at a distance, mobilizing abstract rules associated with standardized procedures, conditioning in this way certain individuals and institutions behaviors and practices. In fact, these technologies operate by standardizing some conducts and actions, which are periodically monitored, facilitating the institutionalization of evaluation routines and accountability as "natural" components of the university's performance that facilitates its adaptation to the changing demands of the market and the economy.

What these new modes of regulation represent is the generalization of the condition for modernity as a society increasingly based on a cyber-anthrop-cratic governance 
under the rules of accounting and accountability (Rose 1999: 151)..$^{7}$ Thanks to the potentialities of the new information technologies, this administrativization of society has achieved levels of control with degrees of freedom that were difficult to imagine until recently (Deleuze 1992). The recording, transmission and processing of information has made it possible to differentiate and classify, facilitating the reorganization of each one of the institutions and their individuals and groups, on the basis of which they report on their own statistics. Throughout the last decade, governmental agencies and other independent centers of calculation created ex-profeso $0^{8}$ have taken responsibility for designing and implementing new mechanisms for steering from a distance, which function through periodical evaluation processes of the production and performance of each institution, program or individual. The competition for scarce resources facilitates regulation over performance, since it stimulates institutions and communities to comply adequately with the functions assigned and the commitments established, and any non-fulfillment is considered an exclusive responsibility of the institution or the individual.

The regulation of the university system under these norms and rules of calculation transform the meaning given to autonomy and the organizational forms used by institutions to guarantee governance. The concept of autonomy is crucial, but no longer understood as a principle of self-determination that leads to the establishment of purposes and projects, ${ }^{9}$ but rather basically as the responsibility of institutions and individuals for their own conduction to fulfill the demands — measured through performance standards - of their external environment. The concept of autonomy acquires a new meaning that emphasizes

7 Cyber-anthrop-cracy is a concept to refer to the current condition of modernity as an organized society based in new arrangement in which an increasing symbiosis between new information technologies, human bodies and bureaucracy is produced. This new human machine in an em-bodied society, exert a deeper and subtle control in open spaces-based on the organization of exchanges, flows and movements, but, simultaneously projects the illusion of the disappearance of bureaucracy and control. For a discussion of this argument see Ibarra-Colado (2006b: 10).

8 There are in Mexico several independent centers of calculation and regulatory agencies on education and science and technology. Among them, it can be mentioned the National Institute for the Evaluation of Education (Instituto Nacional para la Evaluación de la Educación-INEE), the National Center for Higher Education Evaluation (Centro Nacional de Evaluación para la Educación Superior, A.C.-CENEVAL), and the National Committee for Higher Education Evaluation (Comisión Nacional para la Evaluación de la Educación Superior-CONAEVA).

9 According to the VII fraction of the 3erd Constitutional Article, the autonomy regime implies the right of the university community to select its own authorities, freedom in teaching and research, the designation of professors through academic proceedings, approval of its research programs and syllabus, and the development and administration of the university patrimony and resources. Nevertheless, autonomy as such has never been fully concretized. Insufficient funds have effectively served as a mechanism for subordinating "autonomous" universities at critical moments and in response to issues considered to be of critical importance for the government in functions (Domínguez 2000, 2002: 85). 
its essentially operational or practical content, since universities are "forced to be free" (Rose/Miller 1992) and to confront the challenges implied in taking responsibility for themselves in open environments in which their survival depends fundamentally on their own actions and performance. From now on, institutions need to develop abilities to act and take advantage of the opportunities offered by an increasingly competitive, complex and dynamic environment. This is a matter of operational or practical autonomy in which, more than proposing their own challenges, they must essentially respond to the demands imposed by markets and the economy. The role of the State becomes crucial as a mediation agency that structures the university's spaces of action through the operation of new modes of regulation at a distance supported in new centers of calculation, limiting by these means the levels of freedom experienced by institutions and their academic communities. To use the phrase proposed by Hunter (1994: 74), the new university enjoys a "supervised freedom" due to the operation of a complex set of counting, financing, auditing and inspection technologies (Shore/Wright 2000; Power 2004).

In summary, this new "responsible autonomy" accepts freedom to act, but only if the "free" university and the "free" individual accept to act "responsibly", that is, to decide their actions accepting always the institutional rules established for conducting their actions. This is a concept in which the nature, content and organization of the work of universities are beyond their control, and will instead remain under the direction of external entities that will dictate what, how and in what way their functions and duties will be carried out. This new condition is essential when the goods produced in the university are privately appropriated and exchanged on the market.

This same process of subordination has been confronted by academic communities finding themselves bereft of control over their work, and consequently of freedom in teaching and research, and the practical erosion of tenure when a significant amount of the earnings depends on evaluation processes (Ibarra-Colado 1996; Gil et al. 2005). The key to this change, as has been emphasized, rest on the conformation of a new mode of regulation of academic work based on evaluation to be able to access to extraordinary resources allocated based on externally-determined performance standards.

The exercise of autonomy viewed in this way is giving shape to new modes of governance and management that resemble entrepreneurial models and a business style of direction. The incorporation of management and organizational knowledge promises more efficiency and productivity based on a more obedient and disciplined staff. A century after Frederick W, Taylor applied his system of rationalization and control to factory work, universities are incorporating similar technologies and programs to guarantee cooperation in teaching and research under the dictates of the officials and managers of the institution.

\section{From public policy to institutional governance}

The transformation of the modes of regulation from one based on State intervention and politics to another based on "free market" and competition (Ibarra-Colado 2006a), has implied the displacement of the centrality of public policies and the emerging centrality of issues related with institutional governance. The nature and content of those policies have been modified, decreasing direct State actions in favor 
of the establishment and operation of programs in charge of diverse independent centers of calculation. Now, higher education system is regulated through a complex network of organizations to operate evaluation; they design and manage some programs, always with the institution's active participation, based on explicit standardization, so performance is clearly linked with the access to extraordinary resources on a competitive base. Since universities are increasingly responsible for their own actions, institutional governance becomes a condition for being able to operate under the new model. If institutions do not assume their new functions and identity as active establishments pursuing their own specific purposes, they will find it difficult to function under the new regulatory mechanisms and, consequently, will endanger their viability and even their survival.

Public policy analysis broadly influenced the research agendas in higher education throughout the last decade. Nevertheless, the relevance of these analyses as an explanatory approach has been losing ground in favor of perspectives that identify their central core as problems of governance, organization and management. This does not mean that public policies are no longer relevant, but instead that their profile and relative impact is being modified because of transformations in institutional practices and governmental modes of regulation. Undoubtedly, public policy analysis will continue to preserve a relevant role in understanding governmental actions, their recent changes and their effects at the institutional level. They will continue to explain the role of the State as coordinator of the higher education system, and the transformations of the relations it maintains specifically with the university. However, it will be necessary to go beyond to understand precisely and thoroughly the specific dynamics that orient strategies and actions of institutions that are recreating their autonomy and freedom, so they could carry out their own particular projects under new governance structures and organizational forms.

In order to interpret adequately the institutional dynamics of universities in an every-day basis, it will be necessary to address systematically an analysis of their capacities for effective governance, which is associated with management practices and organizational forms to confront the specific conditions of their local environments. In addition, it is necessary to acknowledge that the university system is in a process of "governmentalization" (Foucault 2003a). This process implies the reconstitution of the university as a bureaucratic corporation based on hierarchy, centralization and management to operate in different markets efficiently. This institution's abilities for governing itself by conducting the behavior of its academic communities under certain explicitly-defined projects have become a strategic element, to the extent that there is no longer a protectionist State that grants certain benefits and resources in exchange for political loyalty, something presumably discarded.

As it was already pointed out, the university system is being forced to assume its freedom (Rose/Miller 1992). It must cease to depend on the State, to assume rather fully the responsibilities implied in its decision-making, management and performance. In order to certify the responsible exercising of such freedom, the practice of accountability has become a key element to gain social legitimacy and to obtain the resources 
needed by the institution to continue working on its projects. ${ }^{10}$ These new practices make it possible to monitor at a distance the actions of individuals, programs and institutions using diverse performance indicators, and to operate market-based controls and correctives.

This transformation is highly important, since it returns a key role to university agents to define the specific projects of the institution, displacing the old omnipresence of the State as the only center for planning and coordinating activities. The universities must transform themselves to be able to re-establish themselves as active and constructive agencies capable to participate successfully in an open and dynamic context dominated by changing relations and permanent risks. Nowadays, the university must function in uncertain scenarios based on an increasing participation and coresponsibility. The capacity of doing and doing it well is fundamental, and it requires effective institutional arrangements to generate agreements around common projects. Otherwise, the success of the institution will be impossible.

From this point of view, university governance becomes the strategic element under the new conditions. It implies a structural design and a practical capacity to produce consensus and cooperation, adequately mediating differences between different sectors of the community. Governance is based on reflexive selfacknowledgement to recognize institutional strengths to favor those programs that adequately fit the opportunities detected in their immediate contexts. It represents the institutional capacity to operate with efficacy and legitimacy, and to gain support around a project that synthesize the identity of an institution in which any sector is represented.

Internally, governance has to do with the day-to-day functioning of the institution as a collective project. It supposes the definition and socialization of the institution's main purposes to bring a sense of unity and directionality; the cultivation of those institutional values to orient a rational and ethical behavior of the members of the institution; the design of the structures and procedures for a legitimate decision-making based on transparency and on the respect of agreements and accorded rules; the definition of the different levels of authority considering their functions and responsibilities, and protecting an adequate balance of power; and the scope and modalities of its particular management and organizational forms. It also supposes certain practices to expand its capacity for intervention and response, allowing for the designing of strategies whose effectiveness will depend on the flexibility of its structures. This encompasses certain management styles, and the establishment of rules and routines to enhance work facilitating integration. Governance structure plays a fundamental role in fulfilling the functions of mediation, allowing for the channeling of tensions and conflicts between the various participating agents. In this sense, the institution's capacity for managing its problematic contexts depends to a significant degree on its structures

10 The term accountability is significant since its meaning is inscribed within the logic of accounting, illustrating one of the liberal technologies of governance most used today. This tendency toward the universalization of accountability has led to the identification of a new configuration of society and State in terms of its evaluative role (Power 2004; Rose 1999). 
for governance and management, but also on the capacity these structures provide to anticipate contingencies and conflicts and to contend with them.

Governance also provides the institutional scenario in which the functions of universities are performed, including teaching work and research activities, as well as diffusion activities and exchange and collaboration programs. In addition, it affects specialized management activities such as fund-raising, financial planning, management of labor relations and administration of diverse institutional programs.

Externally, university governance involves managing the relations between the institution and the agencies that participate in common environments, facilitating enhancement processes that would not otherwise occur. Relations with State agencies and independent centers of calculation are essential, since evaluation of performance and access to extraordinary resources depends on them. Relations with enterprises and organizations in the public sector and society are essential to establish agreements and joint projects and to carry them out. These relations require new abilities to facilitate the integration of networks of knowledge production, which in turn requires the coordination of the institution's governance systems with the more general regulatory rules applied to those collaborative groups of organizations (Casas 2001; Luna 2003). For example, the growing participation in joint projects and cooperative programs will demand new structural arrangements that are more flexible and mutually shared, and that make it possible to exploit economies and complementarities that would be impossible to attain on an individual basis. These new arrangements impose restrictions on internal functioning, and to be effectively negotiated the institution requires good governance practices to facilitate communication and agreements.

In summary, a university's level of governance can be evaluated on the basis of its performance and stability, its capacity to respond and adapt, and the cohesion attained by its academic community through its identification with the main institutional project. In this sense, effectiveness and legitimacy are the basic ingredients of the formula for good governance.

\section{Entrepreneurial university, command and control}

The relevance of university governance and management is based on the capacity to translate operationally an institutional project in actions and behaviors that influence society producing certain effects; these arrangements structure the spaces of action of individuals and communities, establishing the frontiers of what is acceptable, and their particular modes of existence or styles of life. However, the main characteristics of university governance already commented can be performed under different organizational forms. One of them that has become popular under the current government policies in Mexico is the entrepreneurial university (Clark 1998), which is considered an "appropriate" form of governance for improving public "over-politicalized" universities. This model reinforces the idea of practical autonomy, which identifies institutions that carry out programs that respond to external demands.

The fundamental characteristic of the entrepreneurial university lies on the systematic adoption of business-like organizational forms and management technologies, and on the incorporation of the rhetorical games of corporations associated with excellence, quality and competition, under the premise that a university is not essentially 
different from any other enterprise and therefore can be handled in the same way. One of the results is that the institution's essential purposes are identified in terms of its "mission", a statement that resume the purposes of those in charge of the institution, and the strategies, programs, goals and objectives that must be performed under the command of officials and managers. The functions of the university are usually represented as a "portfolio of products and services" for the market, always linked to a cost-benefit evaluation and to marketing strategies to capture the attention of "customers". In addition, to improve performance and be able to adapt and change, the entrepreneurial university adopts the current management recipes and applies standardized assessment programs such as the ISO-9000.11

Business-oriented universities are directed by a new type of university official, characterized by his/her extensive capacity in management and in a sense, by the allegation of his/her right to manage such an enterprise. In addition, they assume that the management of the university is a matter for experts, making it necessary to define and differentiate the functions and responsibilities that must be taken by the institution's directors, as well as those directly related to academic positions and those related to the routine administrative management of the institution. Top management will be a centralized position in charge of the relationships between the institution and its environment, and encompasses the definition of the university's mission and main strategies, establishing exchange and cooperation agreements, and addressing the problems arising from highly competitive, uncertain and dynamic markets. Its effectiveness is measured based on standardized certification procedures and accountability; and the possibility for university managers to move up the political ladder depends on effective governance based on good administration, centralized control and efficient performance.

In addition, the entrepreneurial university model introduces new structural arrangements to gradually replace or subordinate democratic or collegial forms of governance with top executive centralized structures that facilitate decision-making under ample degrees of freedom. The collegial decision-making is increasingly seen as an obstacle to the effective functioning of the institution. Discussion in broad-based and diverse settings, often accompanied by mobilizations of activists, seriously hinders the direct, expeditious application of efficiency criteria used for measuring performance. In order to confront these limitations, the entrepreneurial university reduces the size of collegial bodies, and orients them toward advisory-type functions to provide feedback to the university's officials and managers in charge of decision-making. Also, they function with ad hoc commissions to analyze concrete topics, and the consultation of the community is directed by officials who control timelines, modalities and scope of participation. The intention is to produce an induced legitimacy, to the extent that participation operated in this way hinder substantive changes of the proposals and, at

11 Among the most relevant management technologies used in university administration, one could mention: line-item budgeting, cost budgeting, planning, programming and budgeting system (PPBS), zero base budget system, management by objectives, strategic planning in its diverse modalities, benchmarking, total quality management, reengineering and outsourcing (Rourke/Brooks 1967; Keller 1987; Birnbaum 2001). 
the same time, validates the decision or project under consultation. The effectiveness of this process rests on its capacity to displace the content and purposes of such a consultation, and to substitute them with a formal participatory procedure that gives the sense of "having been taking into account."

Another important feature of the entrepreneurial university has to do with financial management, which is considered a matter exclusively for experts who are in charge of designing strategies for obtaining resources that strengthen the institution's independence and capacity for taking actions. This supposes centralized handling of resources, since it expands the margins for negotiation between the institution's officials and each of the institution's sectors, facilitating greater control and expeditious cooperation. The institution operates under mechanisms for controlling resources through on-line information systems that facilitates detailed, precise and instant monitoring of expenditures. This makes it possible to detect anomalies and make adjustments from the institution's central offices. In addition, the budget becomes the fundamental tool used to reinforce governance, since it allows negotiating with individuals and groups the support for their projects according to institutional priorities and their relevance to address market demands.

Finally, the entrepreneurial university incorporates organizational modalities that facilitate greater flexibility and, at the same time, greater command and control. This delicate balance is obtained through a form of institutional management in which individuals and groups carry out their activities while freely determining the best way to do so, however always within the institutional frameworks designed for that purpose. The regulations and policies formally agreed upon are complemented by the design of artificial internal markets that foster competition and productivity. Programs for allocating financial resources based on competition, extraordinary economic incentives based on performance, or scholarships or other performance-based assistance all encourage the normalization of behavior, guaranteeing greater flexibility and discipline in the institution. These new practices reduce the academic community's margins for challenging decisions made by the institution's officials and managers, since budget allocations and the granting of extraordinary remunerations depend on them. Therefore, in the entrepreneurial university there is less participation by academics and students, who instead increasingly focus on their tasks, exercising that practical autonomy that gives them a false sense of self-determination.

In summary, from this perspective, governance and management of universities becomes a problem for top university officials and expert managers who define the conditions for designing and manage high-priority institutional programs, often determining the circumstances and modalities for carrying out those programs. As it has been emphasized here, this model has an impact on the nature, content and organization of academic work carried out by universities, which must be adjusted to the calculable standards that have been externally established and the timelines derived from evaluation procedures. This "new university model" illustrates the tendency toward administrativization as the key of a kind of governance based on command and control, or in other words, toward the predominance of knowledge and practices taken from enterprises to design and manage academic institutions as market-driven educational corporations. 


\section{Conclusion: is there any alternative?}

The confrontation of the entrepreneurial university model is a necessary move if society wants to preserve a university in the service not only of the market and the economy, but to attend the educational needs of impoverished society facilitating social mobility and social justice. This aspiration implicates the re-discussion of governance under a model based on social participation and the reinsertion of self-determination. Mexican public universities need to recover their autonomy condition considering it in a more comprehensive sense as the capacity for an academic community to define its main project and to implement it independently. This supposes, on the one hand, the university control over its purposes and projects, and on the other hand, the access to the economic resources necessary for their complete realization guaranteed by the State. From this perspective, and in clear contrast with the entrepreneurial university model, academic communities play a central role, not only as those who carry out programs originated externally, but essentially, as active participants in the design of the institution's essential activities and projects. With a spark of utopianism, it is possible to define some of the elements that could conduct the negotiation of a participative university...

- that contemplates the exercise of autonomy as a possibility for formulating projects and developing the necessary conditions for fulfilling them;

- that facilitates the construction of opportunities to realize those projects made accessible to all, promoting linkages among those projects on the basis of thoughtful cooperation from the communities promoting them;

- that sustains its legitimacy through its inclusive, decentralized and pluralistic nature, consistently beyond narrowly defined institutional missions or misunderstood highpriority projects;

- that is maintained as a socially self-regulated apparatus, to the extent in which relations between groups and sectors in the community function as an effective institutional mechanism for agreeing upon and/or modifying minimal rules of coexistence;

- that functions with transparency, bringing visibility to everyone's actions through accountability systems that have been collectively agreed upon, strengthening trust in others through scrupulous accomplishment of the ends agreed.

In order to advance toward an alternate organizational model for universities based on the exercise of this fundamental autonomy, and consequently, on the community's pluralistic participation, it is necessary to create and guarantee at least four essential conditions:

1. The establishment of a State policy for universities to protect them from economic crises and decisions based on temporary circumstances, and that grants universities long-term stability and certainty. This will require:

- the definition of a percentage of the Gross Domestic Product as the minimum allocation for promoting education and science;

- the revision of the legislative framework for the university system, in order to eliminate ambiguities in key issues such as autonomy, gratuitous education and state financing obligations; 
- the promotion of the participation of institutions, academic communities and other social groups in the redefinition of the legislative framework.

2. The allocation of extraordinary economic resources to address the accumulated lag of poorest states and institutions and to guarantee the operation of institutional projects that will help to surpass that lag. This will require:

- the designing and operating of extraordinary financing programs, administered by independent civil society agencies to address deficiencies in long-neglected regions and institutions.

3. The exercise of autonomy independent from State regulation, in order to guarantee that the academic communities associated with each institution will effectively decide the specific terms and scopes of their projects. This will require:

- the adoption of evaluation procedures based on academic commitments agreed upon by the institution and its communities;

- the recognition of evaluation as a mechanism for feedback regarding the institution's activities, and consequently, the elimination of all types of financial "punishment" following allegedly negative results;

- the introduction of autonomous collegial bodies integrated in a pluralistic, balanced way, to operate the accountability process without government intervention and with greater transparency.

4. The consolidation of a community with a solid nucleus, based on the regulation of academic careers considering log-term trajectories, and the integration collegiate bodies to facilitate the enhancement of teaching, research and diffusion projects. This will require:

- the enlargement of the number of full-time professors, in relation to those part-time and those hired only to teach specific courses;

- the consolidation of the training and updating programs for academic staff;

- the establishment of an academic-labor regime based on adequate, stable remuneration instead of merit-pay programs, and on suitable conditions for retirement.

The potential characteristics and conditions for the development of an alternative model of university governance are supported in the recreation of its autonomy regime. Its social base can be found in its internal democratization, based on the construction of participative governance. This option indicates the necessity of a renewed social contract to favor education and science as the only way to support simultaneously economic development and social justice. It can be viewed as an initial provocation to animate dialogue and reflection on the current situation of public universities and the specific effects that have been experienced, as they have begun to operate under new market-driven modes of regulation.

\section{References}

ANUIES (2000): La educación superior en el Siglo XXI. Mexico: ANUIES.

ANUIES (2006): Consolidación y avance de la educación superior en México. Mexico: ANUIES.

Aronowitz, S. (2000): The Knowledge Factory: Dismantling the Corporate University and Creating True Higher Learning. Boston, MA: Beacon Press. 
Barrow, C.W. (2002): Globalization, Trade Liberalization, and the Higher Education Industry. In: S. Aronowitz/H. Gautney (Eds.), Implicating Empire: Globalization \& Resistance in the 21st Century World Order. New York: Basic Books: 229-252.

Barrow, C.W. et al. (2003): Globalization, Trade Liberalization, and Higher Education in North America. Amsterdam: Kluwer.

Boltvinik, J./Hernández, E. (2002): Pobreza y distribución del ingreso en México. Mexico: Siglo XXI.

Casas, R. (Ed.) (2001): La formación de redes de conocimiento: una perspectiva regional desde México. Mexico: Anthropos/IIS-UNAM.

Castel, R. (2002): From Manual Workers to Wage Laborers: Transformation of the Social Question. Piscataway, NJ: Transaction.

Cazés, D. et al. (2003): Declaración de Zacatecas. In: D. Cazés/R. Delgado (Eds.) Hacia una política de Estado para la educación superior en México. Mexico: UAZ/Porrúa: 127-130.

Clark, B.R. (1998): Creating Entrepreneurial Universities: Organizational Pathways of Transformation. Oxford: Pergamon Press.

Birnbaum, R. (2001): Management Fads in Higher Education: Where They Come from, What They Do, why They Fail. San Francisco, CA: Jossey-Bass.

CONACYT (2005): Indicadores de actividades científicas y tecnológicas: México 2005. Mexico: CONACYT.

Cortés, F. et al. (2002): Evolución y características de la pobreza en México en la última década del siglo XX. Mexico: SEDESOL.

Deleuze, G. (1992): Postscript on the Societies of Control. In: OCTOBER, 59(Winter): 3-7.

Delgado, G./Saxe, J, (2005): The World Bank and the Privatization of Public Education: A Mexican Perspective. In: Journal for Critical Education Policy Studies, 3(1).

De Wit, H. et al. (Eds.) (2005): Higher Education in Latin America: The International Dimension. Washington, DC: The World Bank.

Diario Oficial (2002): Ley de Ciencia y Tecnología; Ley Orgánica del Consejo Nacional de Ciencia y Tecnología. In: Diario Oficial de la Federación, June 5: 176-202.

Domínguez, R. (2000): Los sofismas del financiamiento universitario. In: H. Casanova/R. Rodríguez (Eds.), Diversidad y convergencia. Estrategias de financiamiento, gestión y reforma de la educación superior. Mexico: CESU-UNAM: 15-78.

Domínguez, R. (2002): La reforma universitaria: el sentido del cambio. In: H. Muñoz (Ed.), Universidad: política y cambio institucional. Mexico: CESU-UNAM/Porrúa: 81-103.

Foucault, M. (2003a): Governmentality. In: P. Rabinow/N. Rose (Eds.), The Essential Foucault. New York, NY: The New Press: 229-245.

Foucault, M. (2003b): The Birth of Biopolitics. In: P. Rabinow/N. Rose (Eds.), The Essential Foucault. New Cork, NY: The New Press: 202-207.

Fox, V. (2006): Anexo Estadístico del Sexto Informe de Gobierno 2005. Mexico: Presidencia de la República.

Gibbons, M. et al. (1994): The New Production of Knowledge. The Dynamics of Science and Research in Contemporary Societies. London: Sage.

Gil, M. et al. (2005): La carrera académica en la Universidad Autónoma Metropolitana: un largo y sinuoso camino. Mexico: Universidad Autónoma Metropolitana.

Hayes, D./Wynyard, R. (Eds.) (2002): The McDonalidization of Higher Education. Westport, CT: Bergin \& Garvey.

Hunter, I. (1994): Rethinking the School: Subjectivity, Bureaucracy, Criticism. Singapore: Allen \& Unwin.

Ibarra-Colado, E. (1996): Excellence At Large: Power, Knowledge and Organizational Forms in Mexican Universities. In: S.R. Clegg/G. Palmer (Eds.): The Politics of Management Knowledge. London: Sage: $99-120$.

Ibarra-Colado, E. (2001): Considering 'New Formulas' for a 'Renewed University': The Mexican Experience. In: Organization, 8(2): 203-217.

Ibarra-Colado, E. (2002): The Concept of a 'New University' in Mexico: Recent Transformations and Perspectives. In: Mexican Journal of Educational Research, 7(14): 75-105. 
Ibarra-Colado, E. (2003): La universidad en México hoy: gubernamentalidad y modernización. Mexico: UNAM/UAM-I/ANUIES.

Ibarra-Colado, E. (2006a): The ethics of globalization. In: S. Clegg/C. Rhodes (Eds.): Management Ethics: Contemporary Contexts. London: Routledge: 32-54.

Ibarra-Colado, E. (2006b): Mexico's Management \& Organization Studies Challenges in the $21^{\text {st }}$ Century: Practices, Knowledges and Re-encounters. In Management Research: The Journal of the Iberoamerican Academy of Management, 4(3): 179-190.

Kanter, R.M. (1997): World Class: Thriving Locally in the Global Economy. New York, NY: Touchstone.

Keller, G. (1987): Academic Strategy. The Management Revolution in American Higher Education. Baltimore, ML: The Johns Hopkins University Press.

Leydesdorff, L./Etzkowitz, H. (2001): The Transformation of University-industry-government Relations. In: Electronic Journal of Sociology, 5(4): http://www.icaap.org/iuicode?1.5.4.1.

Luna, M. (Ed.) (2003): Itinerarios del conocimiento. Formas, dinámicas y contenido. Un enfoque de redes. Mexico: UNAM-IIS/Anthropos.

Nowotny, H. et al. (2001): Re-thinking Science. Knowledge and the Public in an Age of Uncertainty. Oxford: Polity.

OECD (1997): Exámenes de las políticas nacionales de educación. México: educación superior. Paris: OECD.

Power, M. (1997): The Audit Society. Rituals of Verification. London: Oxford University Press.

Power, M. (2004): Counting, Control and Calculation: Reflections on Measuring and Management. In: Human Relations, 57(6): 765-783.

Rodríguez, R./Alcántara, A. (2001): Multilateral Agencies and Higher Education Reform in Latin America. In: Journal of Education Policy, 16(6): 507-525.

Rodríguez, R./Casanova, H. (2005): Higher Education Polices in Mexico in the 1990s: A Critical Balance. In: Higher Education Policy, 18(1): 51-65.

Rose, N. (1999): Powers of Freedom: Reframing Political Thought. Cambridge: Cambridge University Press.

Rose, N./Miller, P. (1992): Political Power Beyond the State: Problematics of Government. In: British Journal of Sociology, 43(2): 173-205.

Rourke, F.E./Brooks, G.E. (1967): The Managerial Revolution in Higher Education. Baltimore, ML: The John Hopkins Press.

Sauvé, P. (2002): Trade, education and the GATS: What's in, what's out, what's all the fuss about? In: Higher Education Management and Policy, 14(3): 48-80.

SEP (2001): Programa Nacional de Educación 2001-2006. Mexico: SEP.

SEP (2003): Informe Nacional sobre la Educación Superior en México. Mexico: SESIC/IESALC/UNESCO.

Shore, C./Wright, S. (2000): Coercive Accountability: the Rise of Audit Culture in Higher Education. In: M. Strathern (Ed.): Audit Cultures: Anthropological Studies in Accountability, Ethics and the Academy. London: Routledge: 57-89.

Slaughter, S./Leslie, L.L. (1997): Academic Capitalism: Politics, Policies, \& the Entrepreneurial University. Baltimore, ML: Johns Hopkins University Press.

Slaughter, S./Rhoades, G. (2004): Academic Capitalism and the New Economy. Markets, State, and Higher Education. Baltimore, ML: Johns Hopkins University Press.

THES (2006): World University Rankings 2006. In: The Times Higher Education Supplement, October 6.

Verger, A./Bonal, X. (2006): Against GATS: the Sense of a Global Struggle. In: Journal for Critical Education Policy Studies, 4(1).

Wallach, L./Woodall, P. (2004): Whose Trade Organization: A Comprehensive Guide to the WTO. New York: The New Press.

World Bank (2004): Poverty in Mexico: An Assessment of Conditions, Trends and Government Strategy. Washington, DC: International Bank for Reconstruction and Development /World Bank. 